ASSIS, Vinicius de; PAMPLONA, Danielle Anne. Princípios orientadores das nações unidas e a complexidade de proteção e respeito aos direitos humanos no combate ao trabalho escravo no Brasil. Revista Eletrônica Direito e Política, Programa de Pós-Graduação Stricto Sensu em Ciência Jurídica da UNIVALI, Itajaí, v.14, n.1, 10 quadrimestre de 2019. Disponível em: www.univali.br/direitoepolitica - ISSN 1980-7791

\title{
PRINCÍPIOS ORIENTADORES DAS NAÇÕES UNIDAS E A COMPLEXIDADE DE PROTEÇÃO E RESPEITO AOS DIREITOS HUMANOS NO COMBATE AO TRABALHO ESCRAVO NO BRASIL
}

\author{
PRINCIPLES GUIDELINES OF THE UNITED NATIONS AND THE COMPLEXITY OF \\ PROTECTION AND RESPECT FOR HUMAN RIGHTS IN COMBATING \\ SLAVE WORK IN BRAZIL
}

\author{
Vinicius de Assis ${ }^{1}$ \\ Danielle Anne Pamplona
}

\section{RESUMO}

Este artigo procura analisar o avanço dos mecanismos de defesa dos direitos humanos perante o poder econômico, em especial acerca do trabalho escravo no Brasil. Para tanto, será discutido o novo balanço de forças entre Estados e empresas; o desenvolvimento da responsabilização das empresas no âmbito internacional pela elaboração dos Princípios Ruggie e o papel da Organização das Nações Unidas. Para uma observação mais prática do problema, é analisado o Relatório do Grupo de Trabalho das Nações Unidas sobre Empresas e Direitos Humanos no Brasil, em que se avalia como o Estado brasileiro e as empresas atuantes no País estão lidando com as demandas dos direitos humanos. E, por fim, considerações mais específicas sobre o trabalho escravo no Brasil e as propostas de enfrentamento desta questão sob a perspectiva dos Princípios Ruggie. Essa pesquisa foi realizada por meio de uma abordagem descritiva e desenvolvida com base em estudos bibliográficos.

PALAVRAS-CHAVE: direito internacional; direitos humanos; empresas; trabalho escravo; Princípios Ruggie.

\section{ABSTRACT}

The purpose of this article is to analyze the mechanisms progress of the human rights protection towards the economic power, in particular slave labor in Brazil.

\footnotetext{
1 Mestre em Direito Econômico e Socioambiental pela Pontifícia Universidade Católica do Paraná (PUCPR). Pesquisador bolsista da Fundação de Amparo ao Desenvolvimento das Ações Científicas e Tecnológicas do Estado de Rondônia (FAPERO). Professor no Curso de Direito da Faculdade Católica de Rondônia (FCR). Advogado. E-mail: vinicius.assis@fcr.edu.br

2 Doutora em Direito pela Universidade Federal de Santa Catarina. Professora Titular do Programa de Pós-Graduação (Mestrado/Doutorado) em Direito da PUCPR. Coordenadora da Clínica de Direitos Humanos da PUCPR. Membro da Diretoria da Global Business and Human Rights Scholars Association. E-mail: dapamplona@pamplonaebraz.com.br
} 
ASSIS, Vinicius de; PAMPLONA, Danielle Anne. Princípios orientadores das nações unidas e a complexidade de proteção e respeito aos direitos humanos no combate ao trabalho escravo no Brasil. Revista Eletrônica Direito e Política, Programa de Pós-Graduação Stricto Sensu em Ciência Jurídica da UNIVALI, Itajaí, v.14, n.1, $1^{0}$ quadrimestre de 2019. Disponível em: www.univali.br/direitoepolitica - ISSN 1980-7791

Therefore, the new balance of forces between States and companies will be discussed; the development of corporate accountability in the international basis until the development of the current model created by John Ruggie; and the three pillars of the Ruggie Principles. For a more practical observation of the problem, the report of the UN Working Group on Business Enterprises and Human Rights in Brazil, which assesses how Brazilian state and companies operating in the country are dealing with human rights, is analyzed. And finally, specific considerations about slave labor in Brazil and the proposals to address this issue from Ruggie Principles perspective. This research was carried out by means of a descriptive approach and developed on the basis of bibliographic studies.

KEYWORD: international law; human rights; business enterprises; slave labor; Ruggie Principles.

\section{INTRODUÇÃO}

A ideia da universalização dos direitos humanos ganhou força após a Segunda Guerra Mundial. Desde então, vem se tentando uma uniformização mínima mundial para a defesa destes direitos. Na ordem contemporânea, começou-se a observar alguns efeitos negativos da globalização e o surgimento de empresas transnacionais, mais poderosas do que alguns Estados nacionais.

Diante da nova perspectiva de incremento da atividade empresarial e aumento do poderio das grandes corporações, a tutela dos direitos humanos, que pelo direito internacional cabe aos Estados, fica fragilizada. Portanto, resta o seguinte problema: quais são os mecanismos de responsabilização de Estados e empresas para a proteção dos direitos humanos?

O objetivo geral do trabalho é analisar o avanço dos mecanismos de defesa dos direitos humanos perante o poder econômico, utilizando do exemplo da defesa do direito humano de não ser submetido a trabalho escravo ou análogo ao escravo no Brasil. Dentre os objetivos específicos estão pesquisar o desenvolvimento da responsabilização das empresas no âmbito internacional até a elaboração do modelo atual criado por John Ruggie, também conhecido como Princípios Ruggie; avaliar o Relatório elaborado pelo Grupo de Trabalho das Nações Unidas sobre Empresas e Direitos Humanos após sua visita ao Brasil e elaborar proposições de 
ASSIS, Vinicius de; PAMPLONA, Danielle Anne. Princípios orientadores das nações unidas e a complexidade de proteção e respeito aos direitos humanos no combate ao trabalho escravo no Brasil. Revista Eletrônica Direito e Política, Programa de Pós-Graduação Stricto Sensu em Ciência Jurídica da UNIVALI, Itajaí, v.14, n.1, 10 quadrimestre de 2019. Disponível em: www.univali.br/direitoepolitica - ISSN 1980-7791

enfrentamento do trabalho escravo e análogo ao escravo sob a perspectiva da dicção dos Princípios Ruggie.

No primeiro capítulo é estabelecido o papel da Organização das Nações Unidas (ONU) na busca da responsabilização de transnacionais por violações a direitos humanos, sendo discutido o novo balanço de forças entre Estados e empresas e os três pilares dos Princípios Ruggie. O segundo capítulo explora o Relatório do Grupo de Trabalho das Nações Unidas sobre Empresas e Direitos Humanos no Brasil, em que se avalia como o Estado brasileiro e as empresas atuantes no País estão lidando com os direitos humanos. E, por fim, o terceiro capítulo faz um breve resumo da evolução normativa no âmbito internacional e no Brasil do trabalho escravo e propostas de enfrentamento do trabalho análogo ao escravo sob a perspectiva dos Princípios Ruggie.

A partir dessas considerações, o presente artigo procura apresentar, resumidamente, por meio de um estudo descritivo analítico, desenvolvido por meio de pesquisa bibliográfica e análise do Relatório do Grupo de Trabalho das Nações Unidas sobre Empresas e Direitos Humanos no Brasil. Parte de premissas gerais para chegar a uma conclusão específica, por meio de método histórico e o comparativo de proposições de responsabilização de empresas e Estados por violações de direitos humanos.

\section{GLOBALIZAÇÃO E O PAPEL DA ONU NA BUSCA DA RESPONSABILIZAÇÃO DE TRANSNACIONAIS POR VIOLAÇÕES A DIREITOS HUMANOS}

A sociedade globalizada com economia e empresas transnacionais ${ }^{3}$, numa realidade de revolução tecnológica e do capitalismo financeiro, subsidiada por

\footnotetext{
3 LIMA, Abili Lázaro Castro de. A globalização econômica e a dissipação dos direitos sociais. A\&C Revista de Direito Administrativo e Constitucional, Belo Horizonte, ano 6, n. 26, p. 37-58, out./dez. 2006, p. 39. O Autor observa o aumento da internacionalização do comércio e por consequência um aumento do comércio mundial, torna os Estados impotentes no controle de fluxo de capitais, vez que há o rompimento de suas fronteiras
} 
ASSIS, Vinicius de; PAMPLONA, Danielle Anne. Princípios orientadores das nações unidas e a complexidade de proteção e respeito aos direitos humanos no combate ao trabalho escravo no Brasil. Revista Eletrônica Direito e Política, Programa de Pós-Graduação Stricto Sensu em Ciência Jurídica da UNIVALI, Itajaí, v.14, n.1, 10 quadrimestre de 2019. Disponível em: www.univali.br/direitoepolitica - ISSN 1980-7791

ideários econômicos neoliberais ${ }^{4}$, leva à imposição de reformas estruturais, com vistas à liberalização do mercado e à desregulamentação do trabalho e do capital.

O fenômeno da globalização alterou o balanço de poderes entre empresas e o Estado. Rompe a capacidade dos Estados em garantir o bem-estar social, em razão dos acertos neoliberais, visto que transfere para organizações financeiras e grandes corporações o poder de decidir sobre questões sociais e econômicas. ${ }^{5}$

Desta feita, a globalização pode ser identificada como um processo de natureza econômico-comercial, por intermédio da qual intensificaram-se os movimentos de comércio, economia e desenvolvimento tecnológico ${ }^{6}$, revelando processo de internalização ou de criação de um mercado advindo do próprio capitalismo, "um mundo moldado pelas novas tecnologias, pelas novas estruturas sociais, por uma nova economia e uma nova cultura". ${ }^{7}$

Para Ulrick $\mathrm{Beck}^{8}$, a globalização é um processo de interferência dos atores transnacionais na soberania, identidade, redes de comunicação, orientações e chance de poder dos Estados nacionais. Afirma, ainda, que globalização cultural não significa homogeneidade mundial, mas sim, que a cultura local se adapta à

\footnotetext{
${ }^{4}$ GABARDO, Emerson. O jardim e a Praça para além do bem e do mal: uma antítese ao critério de subsidiariedade como determinante dos fins do estado social. 2009. 396 f. Tese (Doutorado) - Curso de Doutorado em Direito, Setor de Ciências Jurídicas, Universidade Federal do Paraná, Curitiba, 2009, p. 200. Para o Autor, os postulados neoliberais é uma decisão política que identifica as funções estatais a depender da racionalidade econômica "a partir da idéia inicial de que o Poder Público só pode atuar de forma complementar, pois o protagonista da ação social deve ser o mercado."
}

5 SILVEIRA, Edson Damas da. RAMOS JÚNIOR, Dempsey Pereira. Globalização multicultural, direitos universais humanos e socioambientais. Revista Direito Econômico e Socioambiental, Curitiba, v.2, n.1, p. 11-39, jan/jun. 2011. p. 21.

6 Ulrich Beck ainda referencia acerca dos termos Globalismo: "Designa a concepção de que o mercado mundial bane ou substitui, ele mesmo, a ação política: trata-se, portanto da ideologia do império do mercado mundial, da ideologia do neoliberalismo"; e Globalidade: "Que denomina o fato de que, daqui para a frente, nada que venha a acontecer em nosso planeta será um fenômeno especialmente delimitado, mas o inverso: que todas as descobertas, triunfos e catástrofes afetam a todo o planeta, e que devemos redirecionar e reorganizar nossas vidas e nossas ações em torno do eixo 'global-local' [...] a globalidade designa apenas a nova situação da segunda modernidade". BECK, Ulrich. O que é globalização? Equívocos do globalismo: respostas à globalização. São Paulo: Paz e Terra, 1999 , p. $27 ; 31$.

7 CAPRA, Fritjof. Conexões Ocultas. Ciência para uma vida sustentável (Trad. Marcelo Brandão Cipolla). São Paulo: Editora Cultrix, 2002, p. 141.

8 BECK, Ulrich. O que é Globalização? Equívocos do Globalismo. Respostas à Globalização. Tradução de André Carone. São Paulo: Paz e Terra, 1999. 
ASSIS, Vinicius de; PAMPLONA, Danielle Anne. Princípios orientadores das nações unidas e a complexidade de proteção e respeito aos direitos humanos no combate ao trabalho escravo no Brasil. Revista Eletrônica Direito e Política, Programa de Pós-Graduação Stricto Sensu em Ciência Jurídica da UNIVALI, Itajaí, v.14, n.1, 10 quadrimestre de 2019. Disponível em: www.univali.br/direitoepolitica - ISSN 1980-7791

nova realidade global, o que o autor chama de "glocalização". Este ser em vários locais ao mesmo tempo, o translocal, é que define o global, e, tornar-se parte da cultura local, o localismo, como estratégia empresarial que eleva o significado prático da globalização. ${ }^{9}$

No que se refere ao papel do Estado nesse novo cenário, Danielle Anne Pamplona10 leciona que não se pode conceituar o Estado de Direito apenas por ser um Estado respeitador de leis. É necessário que esse Estado cumpra diversos outros princípios, dentre eles, o princípio da dignidade humana.

[...] o Estado de Direito Positivista, onde pouco importa o conteúdo da lei, mas tão somente, que possa ser efetivamente chamado de lei, o que tornaria obrigatório seu atendimento. Neste tipo de Estado, importa que a lei seja elaborada por quem detenha a competência e que seja fielmente obedecida, o que caracterizaria formalmente 0 Estado de Direito. E este Estado de Direito é formal justamente porque, apesar do título, em verdade, falta-lhe a preocupação com o conteúdo da lei. Se não há preocupação com o conteúdo da lei, não há por que dar ao juiz a chance de verificar se a norma infra-constitucional está adequada ao texto da Constituição; se não há controle da constitucionalidade, não pode existir Estado que garanta os direitos dos indivíduos. E essa é decorrência lógica, já que para que os indivíduos estejam seguros do respeito aos seus direitos, necessário é permitir-Ihes o socorro ao Judiciário sempre que se encontrarem em situação que se lhes configure uma violação. ${ }^{11}$

Para Daniel Wunder Hachem, na nova ordem constitucional abandona-se o reducionismo do positivismo clássico, reconhecendo-se não só a lei formal como parte integrante do ordenamento jurídico, mas também, os princípios

\footnotetext{
${ }^{9}$ BECK, Ulrich. O que é Globalização? Equívocos do Globalismo. Respostas à Globalização. Tradução de André Carone. São Paulo: Paz e Terra, 1999, p. 90.

10 PAMPLONA, Danielle Anne. O processo de decisão de questões políticas pelo Supremo Tribunal Federal - a postura do juiz. Tese apresentada ao Curso de Pós-graduação em Direito da Universidade Federal de Santa Catarina como requisito à obtenção do título de Doutor em Direito em 2006. Disponível em http://www.dominiopublico.gov.br/download/teste/arqs/cp022108.pdf. Acessada em: 05.11.2017.

11 PAMPLONA, Danielle Anne. O processo de decisão de questões políticas pelo Supremo Tribunal Federal - a postura do juiz. Tese apresentada ao Curso de Pós-graduação em Direito da Universidade Federal de Santa Catarina como requisito à obtenção do título de Doutor em Direito em 2006. Disponível em http://www.dominiopublico.gov.br/download/teste/arqs/cp022108.pdf. Acessada em: 05.11.2017.
} 
ASSIS, Vinicius de; PAMPLONA, Danielle Anne. Princípios orientadores das nações unidas e a complexidade de proteção e respeito aos direitos humanos no combate ao trabalho escravo no Brasil. Revista Eletrônica Direito e Política, Programa de Pós-Graduação Stricto Sensu em Ciência Jurídica da UNIVALI, Itajaí, v.14, n.1, 10 quadrimestre de 2019. Disponível em: www.univali.br/direitoepolitica - ISSN 1980-7791

constitucionais explícitos e implícitos e os direitos humanos dos tratados internacionais. ${ }^{12}$

Portanto, no modelo de Estado de Direito contemporâneo, faz-se necessária a garantia de direitos individuais, resguardando o cidadão da força de terceiros, do próprio Estado e também de empresas.

Segundo Marcelo Benacchio e Diogo Vailatti ${ }^{13}$, houve um empoderamento das empresas nas últimas décadas, em especial a partir dos anos 1970, desenvolvendo o que se chama de supercapitalismo. Neste modelo, há um esfacelamento do Estado-Nação, que perdeu espaço para empresas transnacionais, que possuem poderio econômico, financeiro, técnico e informacional superior ao do Estado. Ulrich Beck descreve esse fenômeno:

O aparecimento da globalização permite aos empresários e suas associações a reconquista e o pleno domínio do poder de negociação que havia sido politicamente domesticado pelo Estado de bem-estar social capitalista organizado em bases democráticas. A globalização viabilizou algo que talvez já fosse latente no capitalismo, mas ainda permanecia oculto no seu estágio de submissão ao Estado democrático do bemestar, a saber: que pertence às empresas, especialmente aquelas que atuam globalmente, não apenas um papel central na configuração da economia, mas a própria sociedade como um todo - mesmo que seja "apenas" pelo fato de que ela pode privar a sociedade de fontes materiais (capital, impostos, trabalho). ${ }^{14}$

A perda de controle da arrecadação por parte do Estado modifica toda a dinâmica social. Os direitos sociais acabam por ser relativizados diante do poderio econômico das empresas. Há uma perda de soberania dos Estados, surgindo a supraestatalidade, que é a perda de soberania estatal diante da internacionalização dos processos de decisão, por meio de tratados internacionais;

\footnotetext{
12 HACHEM, Daniel Wunder. A maximização dos direitos fundamentais econômicos e sociais pela via administrativa e a promoção do desenvolvimento. Revista Direitos Fundamentais e Democracia, Curitiba, v.13, n.13, p.340-399, jan/jun.2013. p.348

13 BENACCHIO, Marcelo; VAILATTI, Diogo Basilio. Empresas Transnacionais, Globalização e Direitos Humanos. In: BENACCHIO, Marcelo. A Sustentabilidade da Relação entre Empresas Transnacionais e Direitos Humanos. Editora CRV. Curitiba, 2016
}

14 BECK, Ulrich. O que é Globalização? Equívocos do Globalismo. Respostas à Globalização. Tradução de André Carone. São Paulo: Paz e Terra, 1999, p. 14. 
ASSIS, Vinicius de; PAMPLONA, Danielle Anne. Princípios orientadores das nações unidas e a complexidade de proteção e respeito aos direitos humanos no combate ao trabalho escravo no Brasil. Revista Eletrônica Direito e Política, Programa de Pós-Graduação Stricto Sensu em Ciência Jurídica da UNIVALI, Itajaí, v.14, n.1, $1^{0}$ quadrimestre de 2019. Disponível em: www.univali.br/direitoepolitica - ISSN 1980-7791

e pela livre circulação de mercadorias e trabalho, pondo em xeque políticas protecionistas. ${ }^{15}$

É nesse contexto de Estado enfraquecido e grandes empresas transnacionais, que barganham com Estados em desenvolvimento as melhores condições para o lucro, que a ONU tenta de alguma forma resguardar os direitos dos trabalhadores da "ganância" das grandes corporações.

A preocupação da ONU com os impactos das atividades das empresas transnacionais na sociedade pode ser dividida em três fases. A primeira delas ocorre na década de 1970, quando foi criada a Comissão sobre Multinacionais, que tinha como meta desenvolver um código de conduta que seria implementado pelas empresas.

A segunda fase inicia-se em 1999, com o Grupo de Trabalho sobre Métodos de Trabalho e Atividades das Corporações Transnacionais, que em 2003 apresentou o projeto "Normas sobre Responsabilidades das Corporações Transnacionais e Outros Empreendimentos Privados com Relação aos Direitos Humanos" para aprovação no Conselho de Direitos Humanos. O Conselho não aprovou o projeto e fez duras críticas, por estender obrigações relativas a direitos humanos à empresas, nos moldes das obrigações estatais ${ }^{16}$. A rejeição e as críticas do Conselho a esse segundo projeto abrem a discussão do quão a própria ONU pode ser influenciada politicamente pelo poder do capital, afinal, trata-se de colegiado composto por Estados, que deveriam se mostrar conscientes da gravidade de sua perda de capacidade de fazer frente às vontades das transnacionais.

A terceira fase inicia-se em 2005, com a nomeação de John Ruggie como Representante Especial do Secretário-Geral da ONU para o tema Direitos Humanos

\footnotetext{
15 BECK, Ulrich. O que é Globalização? Equívocos do Globalismo. Respostas à Globalização. Tradução de André Carone. São Paulo: Paz e Terra, 1999.

16 RIBEIRO, Daniela Menengoti; OLIVEIRA, José Sebastião. Promoção e Tutela dos Direitos da Personalidade pelas Empresas Transnacionais. In: BENACCHIO, Marcelo. A Sustentabilidade da Relação entre Empresas Transnacionais e Direitos Humanos. Editora CRV. Curitiba, 2016.
} 
ASSIS, Vinicius de; PAMPLONA, Danielle Anne. Princípios orientadores das nações unidas e a complexidade de proteção e respeito aos direitos humanos no combate ao trabalho escravo no Brasil. Revista Eletrônica Direito e Política, Programa de Pós-Graduação Stricto Sensu em Ciência Jurídica da UNIVALI, Itajaí, v.14, n.1, $1^{0}$ quadrimestre de 2019. Disponível em: www.univali.br/direitoepolitica - ISSN 1980-7791

e Empresas Transnacionais. Para Ribeiro e Oliveira ${ }^{17}$, a nomeação de Ruggie foi fortemente influenciada pelos norte-americanos, que queriam regras mais brandas às empresas. O resultado de seu trabalho é descrito como Pragmatismo Principiológico, por priorizar ações e normatizações com maiores chances de serem alcançadas, baseando-se em princípios.

The Guiding Principles are a transformational roadmap to a future where the billions of people whose lives are impacted by corporate activities are treated with respect for their dignity and fundamental welfare - a world where human beings and corporations alike can thrive and prosper. ${ }^{18}$

Ruggie apresentou relatório intitulado Protect, Respect and Remedy ao Conselho de Direitos Humanos das Nações Unidas em 7 de abril de 2008, baseando-se em três princípios fundamentais: o dever do Estado de proteger os direitos humanos; a responsabilidade das empresas de respeitar os direitos humanos; e a necessidade de reparação efetiva dos direitos violados. Os princípios diferenciam a responsabilidade da empresa (responsabilities) da responsabilidade do Estado (duties), sendo aquela definida pelas expectativas sociais. São trinta e um princípios divididos em três pilares.

Eles estão fundamentados no reconhecimento de que os Estados assumiram obrigações de respeitar, proteger e implementar os direitos humanos e liberdades fundamentais; de que as empresas têm um papel a desempenhar como órgãos especializados da sociedade que desempenham funções especializadas e que devem cumprir todas as leis aplicáveis e respeitar os direitos humanos. ${ }^{19}$

\footnotetext{
17 RIBEIRO, Daniela Menengoti; OLIVEIRA, Jose Sebastião. Promoção e Tutela dos Direitos da Personalidade pelas Empresas Transnacionais. In: BENACCHIO, Marcelo. A Sustentabilidade da Relação entre Empresas Transnacionais e Direitos Humanos. Editora CRV. Curitiba, 2016.

18 Tradução livre dos autores: Os princípios norteadores são um mapa transformador para um futuro onde bilhões de pessoas cujas vidas são impactadas pelas atividades de corporações são tratadas com respeito por sua dignidade e bem-estar fundamental - um mundo onde seres humanos e corporações podem, do mesmo modo, lutar e prosperar. RUGGIE, John. UN Guiding Principles on Business and Human Rights. Disponível em: https://www.shiftproject.org/un-guiding-principles/. Acessado em: 05.11.2017.

19 SILVA, Ana Rachel Freitas da; PAMPLONA, Danielle Anne. Os Princípios Orientadores das Nações Unidas sobre Empresas e Direitos Humanos: houve avanços? In: BENACCHIO, Marcelo (coord.). A Sustentabilidade da Relação entre Empresas Transnacionais e Direitos Humanos. Editora CRV. Curitiba, 2016, p. 154.
} 
ASSIS, Vinicius de; PAMPLONA, Danielle Anne. Princípios orientadores das nações unidas e a complexidade de proteção e respeito aos direitos humanos no combate ao trabalho escravo no Brasil. Revista Eletrônica Direito e Política, Programa de Pós-Graduação Stricto Sensu em Ciência Jurídica da UNIVALI, Itajaí, v.14, n.1, 10 quadrimestre de 2019. Disponível em: www.univali.br/direitoepolitica - ISSN 1980-7791

O primeiro pilar diz respeito ao dever do Estado de proteger os direitos humanos. Os Estados precisam proteger as pessoas de violações a direitos dentro de sua jurisdição. Nesse sentido, os Estados precisam estabelecer claramente como as empresas atuantes em seu território devem agir em conformidade com os direitos humanos.

The first pillar of the Guiding Principles provides recommendations on how states can meet their existing international human rights obligations to protect against business-related human rights abuses by creating an environment that is conducive to business respect for human rights. ${ }^{20}$

A organização Shift ${ }^{21}$ desenvolveu para esse pilar cinco elementos em que o Estado deve se basear. Dentre eles, a busca em atingir uma coerência jurídica e política entre as obrigações quanto aos direitos humanos e o respeito ao empreendedorismo; e a promoção dos direitos humanos nos negócios, tanto internamente quanto no exterior.

Portanto, esse pilar refere-se ao cuidado que o Estado precisa ter para que as leis sejam cumpridas, fiscalizando e assessorando as empresas para que estas obedeçam às regras impostas para o respeito aos direitos humanos. Evidencia a centralização de responsabilidades no Estado, colocando as empresas em uma posição de passividade, em que apenas precisam cumprir o que o governo nacional defina como sendo observância de direitos humanos, sem que tenham um papel mais ativo, como pode ser observado nos próximos pilares.

O segundo pilar refere-se à responsabilidade das empresas em respeitar os direitos humanos. O foco desse pilar é que a empresa se balize nos princípios trazidos para

20 Tradução livre dos autores: O primeiro pilar dos Princípios Orientadores provê recomendações sobre como os Estados podem cumprir com as existentes obrigações internacionais de direitos humanos para proteger em face de abusos de direitos humanos relacionados com empresas criando um ambiente que seja condutor de respeito empresarial por direitos humanos. SHIFT. Pillar I: State Duty to Protect. Disponível em https://www.shiftproject.org/resources/protect/ . Acessado em 07.11.2017.

${ }^{21}$ A Organização Shift foi fundada em junho de 2011, por Caroline Rees e Rachel Davis, membros da equipe do Representante Especial do Secretário-Geral da ONU sobre Empresas e Direitos Humanos, John Ruggie. Seu foco voltou-se para a implementação dos Princípios Orientadores das Nações Unidas sobre Empresas e Direitos Humanos. SHIFT. Pillar I: State Duty to Protect. Disponível em https://www.shiftproject.org/resources/protect/. Acessado em 07.11.2017. 
ASSIS, Vinicius de; PAMPLONA, Danielle Anne. Princípios orientadores das nações unidas e a complexidade de proteção e respeito aos direitos humanos no combate ao trabalho escravo no Brasil. Revista Eletrônica Direito e Política, Programa de Pós-Graduação Stricto Sensu em Ciência Jurídica da UNIVALI, Itajaí, v.14, n.1, $1^{0}$ quadrimestre de 2019. Disponível em: www.univali.br/direitoepolitica - ISSN 1980-7791

que não haja violação dos direitos humanos nas relações com funcionários, clientes, colaboradores e fornecedores. Esta responsabilidade envolve o dever das empresas em avaliar o impacto real e potencial de suas atividades. Para os princípios, a avaliação e definição do potencial impacto que a atividade pode ter sobre direitos humanos é o primeiro passo para que a empresa defina ações que evitem tais impactos, mas, para além disso, para que a empresa prepare seu plano de ação para o caso de ocorrência de alguma violação.

São oito elementos que acompanham o segundo pilar, mas, além deles, indicados pela Shift ${ }^{22}$, as empresas precisam observar alguns conceitos abrangentes. Dentre eles: a observação não apenas do risco de negócio, mas também no risco humano dos negócios; a responsabilidade de respeitar os direitos humanos não apenas para a própria empresa, mas que esta se preocupe com toda a cadeia de relacionamentos de fornecedores e produtores; e ainda que a filantropia não compense os impactos negativos trazidos pela empresa. Este último tópico é bastante importante eis que as empresas, em um primeiro momento, passaram a se preocupar com sua responsabilidade social e a demonstrar isso por meio de ações voltadas ao cuidado com o meio ambiente, ou com a infância. Assim, não são poucos os casos de empresas que se comprometem a cuidar de canteiros no entorno de sua sede, ou que instituem creches para os filhos de seus funcionários e debitam tais ações, à responsabilidade social corporativa ${ }^{23}$. Pois bem, a preocupação da Shift, aqui, é deixar claro que o cumprimento dos princípios vai além disso. Faz-se necessário um compromisso que extrapole as ações de responsabilidade social e que indiquem o comprometimento da empresa em avançar no respeito aos direitos humanos que possam ser impactados por sua atividade.

O terceiro pilar trata do acesso a mecanismos de reparação, sendo uma lógica aplicável tanto para empresas quanto para Estados. Estes devem incluir

22 SHIFT. Pillar I: State Duty to Protect. Disponível em https://www.shiftproject.org/resources/protect/ . Acessado em 07.11.2017.

23 Sobre a responsabilidade social corporativa, ver BAUMANN-PAULY, Dorothée. Managing

Corporate Legitimacy, a toolkit, 2013. 
ASSIS, Vinicius de; PAMPLONA, Danielle Anne. Princípios orientadores das nações unidas e a complexidade de proteção e respeito aos direitos humanos no combate ao trabalho escravo no Brasil. Revista Eletrônica Direito e Política, Programa de Pós-Graduação Stricto Sensu em Ciência Jurídica da UNIVALI, Itajaí, v.14, n.1, $1^{0}$ quadrimestre de 2019. Disponível em: www.univali.br/direitoepolitica - ISSN 1980-7791

mecanismos para receber e analisar reclamações das vítimas, incluindo alternativas não judiciais para reparação de danos $^{24}$. Nesse sentido,

1. As part of their duty to protect, states must take appropriate steps to ensure that when abuses occur, victims have access to effective judicial and non-judicial statebased grievance mechanisms; ${ }^{25}$

É necessário, portanto, que a ação do Estado para estabelecer tais mecanismos seja prévia. É algo que deve acontecer antes que os abusos ocorram. O Estado tem o dever de estar preparado para socorrer as vítimas em termos de maneiras para que elas possam verbalizar e expor as violações das quais sejam vítimas. Esse é o reconhecimento de que as violações poderão ocorrer, por melhor que estejam, Estados e empresas, preparados ou preocupados com a prevenção. Assim, se as medidas preventivas não forem suficientes - ou sequer forem tomadas - este tópico se preocupa em como o Estado estará preparado para receber a notícia e encaminhar o assunto.

2. Non-state-based grievance mechanisms should complement state-based mechanisms. This includes mechanisms at the operational level (meaning that companies are involved in implementing them), at a national level, or as part of multistakeholder initiatives or international institutions; ${ }^{26}$

3. All non-judicial grievance mechanisms should meet key effectiveness criteria by being legitimate, accessible, predictable, equitable, transparent, rightscompatible, a source of continuous learning, and (in the case

\footnotetext{
24 SILVA, Ana Rachel Freitas da; PAMPLONA, Danielle Anne. Os Princípios Orientadores das Nações Unidas sobre Empresas e Direitos Humanos: houve avanços? In: BENACCHIO, Marcelo (coord.). A Sustentabilidade da Relação entre Empresas Transnacionais e Direitos Humanos. Editora CRV. Curitiba, 2016.

25 Tradução livre dos autores: Como parte de seu dever de proteger, os Estados devem tomar as medidas apropriadas para assegurar que quando um abuso ocorra, as vítimas tenham acesso a mecanismos de queixa estatais efetivos, judiciais e não-judiciais. SHIFT. Pillar I: State Duty to Protect. Disponível em https://www.shiftproject.org/resources/protect/ . Acessado em 07.11.2017.

26 Tradução livre dos autores: Mecanismos de queixa não estatais devem complementar os mecanismos estatais. Isso inclui mecanismos no nível operacional (significa que as empresas devem estar envolvidas neles), no nível nacional, ou como parte de iniciativas de todos os interessados ou de instituições internacionais. SHIFT. Pillar I: State Duty to Protect. Disponível em https://www.shiftproject.org/resources/protect/ . Acessado em 07.11.2017.
} 
ASSIS, Vinicius de; PAMPLONA, Danielle Anne. Princípios orientadores das nações unidas e a complexidade de proteção e respeito aos direitos humanos no combate ao trabalho escravo no Brasil. Revista Eletrônica Direito e Política, Programa de Pós-Graduação Stricto Sensu em Ciência Jurídica da UNIVALI, Itajaí, v.14, n.1, 10 quadrimestre de 2019. Disponível em: www.univali.br/direitoepolitica - ISSN 1980-7791

of operational-level mechanisms) based on dialogue and engagement ${ }^{27}$.

Perceba-se que, ao contrário das propostas anteriores, a análise destes princípios conduz à conclusão de que há indicações de procedimento para as empresas, mas não há imposição de obrigações às corporações. Sugerem o envolvimento de empresas em mecanismos de queixas não estatais e não judiciais, com critérios previsíveis e dentro do direito, entre outros, fundados no diálogo e compromisso.

O modelo atual apresenta princípios que guiam as empresas, não atrelam estas a responsabilidades reais, consolidando a ideia de triunfo das empresas no dito supercapitalismo. As responsabilidades (duties) reais acabaram permanecendo com o Estado, que, como se viu anteriormente, perde espaço e poder para as grandes empresas.

Silva e Pamplona ${ }^{28}$ trazem diversas críticas ao modelo atual, por não ter regras mais incisivas para as empresas. Citam a Anistia Internacional, que cobrou por mais clareza nas medidas legais que os Estados podem tomar para maior regulação das empresas, e a ONG Human Rights Advocate, que entende que os princípios deixam aos governos nacionais a incumbência de definir o que é observar os direitos humanos.

Estas críticas deixam cristalina a ideia de que a
responsabilidade de respeitar os Direitos Humanos deve
abranger Estados, pessoas naturais e jurídicas,
independentemente da forma societária ou da extensão de
suas atividades. Qualquer pessoa jurídica, com finalidade
lucrativa ou não, de pequeno ou grande porte, com atividades
restritas ao território de um país ou com operações
internacionais, é corresponsável pela proteção dos Direitos
Humanos. Entretanto, a responsabilização das empresas
multinacionais ou transnacionais apresenta dificuldades

27 Tradução livre dos autores: Todos os mecanismos de queixa não judiciais devem preencher critérios chave de eficácia sendo legítimos, acessíveis, previsíveis, equitativos, transparentes, compatíveis com direitos, fontes de aprendizado contínuo, e (no caso de mecanismos do nível operacional) baseados no diálogo e no compromisso. SHIFT. Pillar I: State Duty to Protect. Disponível em https://www.shiftproject.org/resources/protect/ . Acessado em 07.11.2017.

28 SILVA, Ana Rachel Freitas da; PAMPLONA, Danielle Anne. Os Princípios Orientadores das Nações Unidas sobre Empresas e Direitos Humanos: houve avanços? In: BENACCHIO, Marcelo (coord.). A Sustentabilidade da Relação entre Empresas Transnacionais e Direitos Humanos. Editora CRV. Curitiba, 2016. 
ASSIS, Vinicius de; PAMPLONA, Danielle Anne. Princípios orientadores das nações unidas e a complexidade de proteção e respeito aos direitos humanos no combate ao trabalho escravo no Brasil. Revista Eletrônica Direito e Política, Programa de Pós-Graduação Stricto Sensu em Ciência Jurídica da UNIVALI, Itajaí, v.14, n.1, $1^{0}$ quadrimestre de 2019. Disponível em: www.univali.br/direitoepolitica - ISSN 1980-7791

adicionais pela multiplicidade de jurisdições envolvidas no exercício de suas atividades. Além disso, possuem, em geral, grande poder econômico e influência sobre Estados ansiosos por atrair capital estrangeiro. ${ }^{29}$

As empresas transnacionais podem utilizar sua posição de provedoras de recursos financeiros para afastar normas que as responsabilizem e reduzam seu espaço de atuação ${ }^{30}$. Podem, portanto, navegar entre jurisdições, selecionando as que the são mais favoráveis. Nesse contexto, as chances de os stakeholders externos, vítimas de abusos cometidos por multinacionais, terem seus direitos reparados diminuem ante a força econômica.

Portanto, os princípios orientadores sobre empresas e direitos humanos elaborados pelo representante especial do Secretário-Geral das Nações Unidas, John Ruggie, não impuseram maior responsabilização das empresas por meio de regras mais incisivas sobre suas obrigações a essas empresas, em razão do seu caráter sugestivo sem que tenham um caráter cogente.

\section{RELATÓRIO DO GRUPO DE TRABALHO DAS NAÇÕES UNIDAS SOBRE EMPRESAS E DIREITOS HUMANOS NO BRASIL}

No período de 7 a 16 de dezembro de 2015, dois membros do Grupo de Trabalho das Nações Unidas, Pavel Sulyandziga e Dante Pesce, visitaram o Brasil para desenvolver um relatório sobre Empresas e Direitos Humanos. Houve inúmeras reuniões com autoridades, empresas e organizações da sociedade civil para

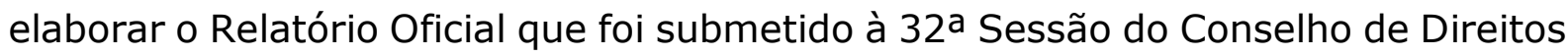
Humanos em Junho de $2016 .{ }^{31}$

\footnotetext{
29 SILVA, Ana Rachel Freitas da; PAMPLONA, Danielle Anne. Os Princípios Orientadores das Nações Unidas sobre Empresas e Direitos Humanos: houve avanços? In: BENACCHIO, Marcelo (coord.). A Sustentabilidade da Relação entre Empresas Transnacionais e Direitos Humanos. Editora CRV. Curitiba, 2016, p. 159/160.

30 SILVA, Ana Rachel Freitas da; PAMPLONA, Danielle Anne. Os Princípios Orientadores das Nações Unidas sobre Empresas e Direitos Humanos: houve avanços? In: BENACCHIO, Marcelo (coord.). A Sustentabilidade da Relação entre Empresas Transnacionais e Direitos Humanos. Editora CRV. Curitiba, 2016.

31 UNITED NATIONS. Report of the Working Group on the issue of human rights and transnational corporations and other business enterprises on its mission to Brazil.
} 
ASSIS, Vinicius de; PAMPLONA, Danielle Anne. Princípios orientadores das nações unidas e a complexidade de proteção e respeito aos direitos humanos no combate ao trabalho escravo no Brasil. Revista Eletrônica Direito e Política, Programa de Pós-Graduação Stricto Sensu em Ciência Jurídica da UNIVALI, Itajaí, v.14, n.1, 10 quadrimestre de 2019. Disponível em: www.univali.br/direitoepolitica - ISSN 1980-7791

Nesse período da visita, o país passava por turbulências políticas e econômicas que envolviam vários fatores como recessão econômica, processo de impeachment contra a presidente da República e corrupção envolvendo grandes empresas brasileiras e políticos de todo o País. Esse fato deve ser levado em consideração na leitura das recomendações dadas.

O Grupo de Trabalho observou que, em geral, as grandes empresas, tanto privadas quanto públicas, não conhecem os Princípios Orientadores das Nações Unidas, e mesmo as poucas que conhecem não efetivam de fato ações nesse sentido. $E$ mais: "Entre as empresas que conhecem os Princípios Orientadores, o Grupo de Trabalho observou que elas tendem a ver os riscos aos direitos humanos como ameaças para a empresa, em vez de riscos enfrentados pelos detentores vulneráveis de tais direitos". ${ }^{32}$

No entanto, não foram apontados apenas pontos negativos. Destacam também alguns pontos positivos como a adesão da Confederação Nacional da Indústria (CNI) à Declaração do Bahrein, que demanda a implementação dos Princípios Orientadores, bem como a realização de um evento governamental no qual empresas estatais se comprometeram a observar as Diretrizes da Organização para a Cooperação e Desenvolvimento Econômico (OCDE). ${ }^{33}$

Apesar desses avanços, o grupo observou pouca supervisão estatal em grandes projetos de infraestrutura, considerando a ausência do Estado como um ponto problemático para os direitos humanos.

O relatório apresentado abordou: as problemáticas da construção da Hidrelétrica de Belo Monte; o desastre de Mariana; e obras para as Olimpíadas de 2016; dentre

\footnotetext{
Disponível em https://documents-ddsny.un.org/doc/UNDOC/GEN/G16/096/43/PDF/G1609643.pdf?OpenElement. Acessado em 09.11 .2017$.
}

32 UNITED NATIONS. Declaração ao final da visita ao Brasil do Grupo de Trabalho das Nações Unidas sobre Empresas e Direitos Humanos. Disponível em http://www.ohchr.org/Documents/Issues/Business/WG_Visits/20151215_EOM_statement_Brazil_p ortuguese.pdf. Acessado em 09.11.2017.

33 UNITED NATIONS. Declaração ao final da visita ao Brasil do Grupo de Trabalho das Nações Unidas sobre Empresas e Direitos Humanos. Disponível em http://www.ohchr.org/Documents/Issues/Business/WG_Visits/20151215_EOM_statement_Brazil_p ortuguese.pdf. Acessado em 09.11.2017. 
ASSIS, Vinicius de; PAMPLONA, Danielle Anne. Princípios orientadores das nações unidas e a complexidade de proteção e respeito aos direitos humanos no combate ao trabalho escravo no Brasil. Revista Eletrônica Direito e Política, Programa de Pós-Graduação Stricto Sensu em Ciência Jurídica da UNIVALI, Itajaí, v.14, n.1, 10 quadrimestre de 2019. Disponível em: www.univali.br/direitoepolitica - ISSN 1980-7791

outras questões. Quanto a Belo Monte, interessante observar que mesmo a usina estando quase pronta, muitas das condições impostas para o licenciamento relativas à mitigação dos impactos negativos sociais e ambientais não haviam sido implementadas. O Grupo de Trabalho "observou falhas significativas na implementação dos projetos para mitigar os impactos sociais negativos, o que resultou em tensões e protestos." Não houve ainda consulta às populações ribeirinhas que foram reassentadas longe dos rios (sua principal fonte de sustento) sem nenhuma estrutura. ${ }^{34}$

Quanto ao desastre de Mariana, o Grupo de Trabalho discutiu com funcionários da empresa Vale, autoridades estaduais e comunidades sobre a tragédia do rompimento da barragem de rejeitos do Fundão no distrito de Mariana, sendo considerado o maior desastre ambiental brasileiro. Foram lançados 60 milhões de metros cúbicos de resíduos de mineração no Rio Doce, inundando povoados e matando 19 pessoas. A lama percorreu mais de 600 quilômetros até atingir o litoral, matando peixes, fauna e flora e ainda deixando comunidades inteiras sem acesso a água potável.

Com relação a esses fatos, o grupo fez as seguintes observações: havia uma incerteza das comunidades afetadas sobre o próprio futuro, não havia confiança de que a empresa arcaria com as compensações a longo prazo; houve um lapso de duas semanas até que a empresa alertasse o público de outras duas estruturas que também apresentavam riscos, Santarém e Selinha; a empresa não informou às comunidades sobre os riscos da lama; e ainda a não comunicação pela empresa ou Defesa Civil do rompimento da barragem às comunidades que seriam afetadas. Bento Rodrigues, que foi a primeira comunidade a ser afetada, foi atingida após 10 horas do rompimento da barragem. Caso tivesse sido feita a comunicação, as pessoas poderiam ter retirado pertences e ainda salvo vidas. ${ }^{35}$

\footnotetext{
34 UNITED NATIONS. Declaração ao final da visita ao Brasil do Grupo de Trabalho das Nações Unidas sobre Empresas e Direitos Humanos. Disponível em http://www.ohchr.org/Documents/Issues/Business/WG_Visits/20151215_EOM_statement_Brazil_p ortuguese.pdf. Acessado em 09.11.2017.
}

35 UNITED NATIONS. Declaração ao final da visita ao Brasil do Grupo de Trabalho das Nações Unidas sobre Empresas e Direitos Humanos. Disponível em 
ASSIS, Vinicius de; PAMPLONA, Danielle Anne. Princípios orientadores das nações unidas e a complexidade de proteção e respeito aos direitos humanos no combate ao trabalho escravo no Brasil. Revista Eletrônica Direito e Política, Programa de Pós-Graduação Stricto Sensu em Ciência Jurídica da UNIVALI, Itajaí, v.14, n.1, 10 quadrimestre de 2019. Disponível em: www.univali.br/direitoepolitica - ISSN 1980-7791

Observa-se que mesmo com toda a atenção da mídia sobre o caso, por causa das suas proporções, a empresa não alertou as comunidades sobre os riscos da invasão da lama e demorou mais de duas semanas para informar sobre o perigo de rompimento de outras duas barragens, ficando evidente a visão que os direitos humanos representam uma ameaça à empresa e não, um tema que deve gerar preocupação por conta dos riscos enfrentados pelas pessoas potencialmente afetadas.

O terceiro e último caso específico abordado pelo grupo foi o das obras das Olimpíadas de 2016 no Rio de Janeiro. Na Vila Autódromo entre 50 e 100 pessoas se recusaram a deixar suas casas por não haver fundamento jurídico para a desapropriação, pois o projeto é privado, não sendo caracterizado como interesse público. No entanto, em junho de 2015, houve confronto violento quando a Guarda Municipal tentou romper uma corrente humana que protegia duas casas de serem demolidas. ${ }^{36}$

Transversalmente a essas questões, o Grupo de Trabalho observou a falta de consulta prévia nas grandes obras brasileiras, que poderiam mitigar impactos negativos aos direitos humanos. Analisou, ainda, que em outros canteiros de obras a não observância da consulta, somada à falta de planejamento, levou ao repentino crescimento da população acompanhada de casos de violência, tráfico, exploração sexual e alcoolismo. ${ }^{37}$

O relatório trata também das questões indígenas e quilombolas. O grupo se alarmou com os conflitos sociais violentos e com os dados de que 138 indígenas foram assassinados em 2014, sendo 41 deles, quase um terço, apenas em Mato

http://www.ohchr.org/Documents/Issues/Business/WG_Visits/20151215_EOM_statement_Brazil_p ortuguese.pdf. Acessado em 09.11.2017.

36 UNITED NATIONS. Declaração ao final da visita ao Brasil do Grupo de Trabalho das Nações Unidas sobre Empresas e Direitos Humanos. Disponível em http://www.ohchr.org/Documents/Issues/Business/WG_Visits/20151215_EOM_statement_Brazil_p ortuguese.pdf. Acessado em 09.11.2017.

37 UNITED NATIONS. Declaração ao final da visita ao Brasil do Grupo de Trabalho das Nações Unidas sobre Empresas e Direitos Humanos. Disponível em http://www.ohchr.org/Documents/Issues/Business/WG_Visits/20151215_EOM_statement_Brazil_p ortuguese.pdf. Acessado em 09.11.2017. 
ASSIS, Vinicius de; PAMPLONA, Danielle Anne. Princípios orientadores das nações unidas e a complexidade de proteção e respeito aos direitos humanos no combate ao trabalho escravo no Brasil. Revista Eletrônica Direito e Política, Programa de Pós-Graduação Stricto Sensu em Ciência Jurídica da UNIVALI, Itajaí, v.14, n.1, $1^{0}$ quadrimestre de 2019. Disponível em: www.univali.br/direitoepolitica - ISSN 1980-7791

Grosso do Sul. E mais a expansão do agronegócio, que vem forçando povos inteiros a sair de suas terras. ${ }^{38}$

No que diz respeito a mecanismos não judiciais para a solução de conflitos, o texto aponta que não há no País uma instituição em nível nacional independente referente aos direitos humanos. Mas que há a Comissão Nacional de Direitos Humanos composta por instituições governamentais, Ministério Público e sociedade civil. Um ponto positivo brasileiro, para o Grupo de Trabalho, é a atividade do Ministério Público, tanto na esfera federal quanto nas estaduais. 0 relatório cita a importância da "independência" da instituição, que, no art. 127 §20 da Constituição Federal ${ }^{39}$, está descrito como autonomia.

Observa-se que a maioria dos problemas citados pelo relatório poderia ser evitada caso houvesse divulgação e efetivação por parte do governo dos Princípios Ruggie, tanto para as empresas quanto para a sociedade em geral, bem como a implementação do primeiro pilar por parte do Estado, havendo efetiva fiscalização nas atividades empresariais. Grande parte do ocorrido se deve ao fato de que muitas das violações não são sequer apuradas e as que são apuradas e as empresas responsabilizadas, recebem punições inferiores aos ganhos com as condutas lesivas a direitos humanos.

O Grupo de Trabalho conclui com vinte e uma recomendações para o governo brasileiro, sete para empresas estatais e privadas e quatro para a sociedade civil organizada. ${ }^{40}$

\footnotetext{
38 UNITED NATIONS. Declaração ao final da visita ao Brasil do Grupo de Trabalho das Nações Unidas sobre Empresas e Direitos Humanos. Disponível em http://www.ohchr.org/Documents/Issues/Business/WG_Visits/20151215_EOM_statement_Brazil_p ortuguese.pdf. Acessado em 09.11.2017.
}

39 BRASIL. Constituição (1988). Constituição da República Federativa do Brasil. Brasília, DF: Senado Federal: Centro Gráfico, 1988.

40 UNITED NATIONS. Report of the Working Group on the issue of human rights and transnational corporations and other business enterprises on its mission to Brazil. Disponível em https://documents-ddsny.un.org/doc/UNDOC/GEN/G16/096/43/PDF/G1609643.pdf?OpenElement. Acessado em 09.11.2017. 
ASSIS, Vinicius de; PAMPLONA, Danielle Anne. Princípios orientadores das nações unidas e a complexidade de proteção e respeito aos direitos humanos no combate ao trabalho escravo no Brasil. Revista Eletrônica Direito e Política, Programa de Pós-Graduação Stricto Sensu em Ciência Jurídica da UNIVALI, Itajaí, v.14, n.1, 10 quadrimestre de 2019. Disponível em: www.univali.br/direitoepolitica - ISSN 1980-7791

Uma recomendação tangível refere-se à importância do Banco Nacional de Desenvolvimento Econômico e Social (BNDES) como atuação do Estado:

Encourage the Brazilian Development Bank (BNDES) to ensure that bank-funded projects include safeguards against adverse human rights impacts, in line with the Guiding Principles. ${ }^{41}$

O BNDES desempenha um papel de extrema importância no desenvolvimento de grande escala do País. Portanto, necessárias as exigências bem definidas sobre os projetos que financia, em cumprimento ao art. $4^{\circ}$ da Lei no 11.948/2009, que impede a concessão e renovação de empréstimos a condenados por assédio moral ou sexual, racismo, trabalho infantil, trabalho escravo ou crime contra o meio ambiente.

Outra recomendação feita é a de criar plataformas e fortalecer mecanismos de diálogos entre o governo, empresas e sociedade civil sobre direitos humanos, como se pode ver na recomendação número 5 para o governo:

Create platforms and strengthen mechanisms for dialogue between Government, businesses and civil society on business and human rights issues. ${ }^{42}$

Outra recomendação dada ao governo brasileiro foi de que este reforce a importância de seguir os Princípios Guiadores para Empresas e Direitos Humanos e das Diretrizes para Empresas Multinacionais da OECD, indicados para empresas privadas e estatais, bem como reforçar os compromissos realizados por empresas estatais já comprometidas em cumpri-los.

\footnotetext{
41 Tradução livre dos autores: Encorajar que o BNDES assegure que os projetos por ele financiados incluam proteções contra impactos adversos em direitos humanos, de acordo com os Princípios Guiadores. UNITED NATIONS. Report of the Working Group on the issue of human rights and transnational corporations and other business enterprises on its mission to Brazil. Disponível em https://documents-ddsny.un.org/doc/UNDOC/GEN/G16/096/43/PDF/G1609643.pdf?OpenElement. Acessado em 09.11 .2017 , p. 21.

42 Tradução livre dos autores: Criar plataformas e fortalecer mecanismos de diálogo entre governo, empresas e sociedade civil sobre temas de empresas e direitos humanos. UNITED NATIONS. Report of the Working Group on the issue of human rights and transnational corporations and other business enterprises on its mission to Brazil. Disponível em https://documents-ddsny.un.org/doc/UNDOC/GEN/G16/096/43/PDF/G1609643.pdf?OpenElement. Acessado em 09.11 .2017 , p. 21.
} 
ASSIS, Vinicius de; PAMPLONA, Danielle Anne. Princípios orientadores das nações unidas e a complexidade de proteção e respeito aos direitos humanos no combate ao trabalho escravo no Brasil. Revista Eletrônica Direito e Política, Programa de Pós-Graduação Stricto Sensu em Ciência Jurídica da UNIVALI, Itajaí, v.14, n.1, 10 quadrimestre de 2019. Disponível em: www.univali.br/direitoepolitica - ISSN 1980-7791

Reinforce the importance of compliance with the Guiding Principles on Business and Human Rights and the OECD Guidelines for Multinational Enterprises in relation to domestic and overseas business activity and highlight the progress made by State-owned enterprises that have already committed to such compliance. ${ }^{43}$

Como tratado nas observações gerais no início da declaração do Grupo de Trabalho ao final da visita ao país ${ }^{44}$, as associações empresariais em geral não conhecem os Princípios Orientadores das Nações Unidas e afirmam ter pouca ou nenhuma informação vinda do governo acerca do assunto, razão pela qual, necessária a supressão dessa lacuna de atuação.

Das recomendações para as empresas, pode-se destacar:

Comply with their responsibility to respect international human rights by adopting a human rights policy and carrying out human rights due diligence to identify, prevent, mitigate and account for how they address adverse human rights impacts. ${ }^{45}$

Essa primeira recomendação é orientadora às empresas no sentido de respeito aos direitos humanos, com sua identificação, prevenção, mitigação e transparência na forma em que abordam os impactos adversos.

43 Tradução livre dos autores: Reforçar a importância de observância dos Princípios Guiadores para Empresas e Direitos Humanos e das Diretrizes para Empresas Multinacionais da OECD em relação às atividades empresariais domésticas e no exterior e realçar o progresso feito por empresas estatais que já se comprometeram com essa observância. UNITED NATIONS. Report of the Working Group on the issue of human rights and transnational corporations and other business enterprises on its mission to Brazil. Disponível em https://documents-ddsny.un.org/doc/UNDOC/GEN/G16/096/43/PDF/G1609643.pdf?OpenElement. Acessado dia 09.11 .2017 , p. 21.

44 UNITED NATIONS. Declaração ao final da visita ao Brasil do Grupo de Trabalho das Nações Unidas sobre Empresas e Direitos Humanos. Disponível em http://www.ohchr.org/Documents/Issues/Business/WG_Visits/20151215_EOM_statement_Brazil_p ortuguese.pdf. Acessado em 09.11.2017.

45 Tradução livre dos autores: Observar sua responsabilidade de respeitar os direitos humanos internacionais adotando políticas de direitos humanos e executando a devida diligência em direitos humanos para identificar, prevenir, mitigar e responder pelo modo com que enfrentam impactos adversos nos direitos humanos. UNITED NATIONS. Report of the Working Group on the issue of human rights and transnational corporations and other business enterprises on its mission to Brazil. Disponível em https://documents-ddsny.un.org/doc/UNDOC/GEN/G16/096/43/PDF/G1609643.pdf?OpenElement. Acessado em 09.11 .2017 , p. 22. 
ASSIS, Vinicius de; PAMPLONA, Danielle Anne. Princípios orientadores das nações unidas e a complexidade de proteção e respeito aos direitos humanos no combate ao trabalho escravo no Brasil. Revista Eletrônica Direito e Política, Programa de Pós-Graduação Stricto Sensu em Ciência Jurídica da UNIVALI, Itajaí, v.14, n.1, 10 quadrimestre de 2019. Disponível em: www.univali.br/direitoepolitica - ISSN 1980-7791

A segunda recomendação dispõe sobre a necessidade de avaliação dos reais impactos adversos, por meio de consulta em comunidades potencialmente afetadas, assegurando informações completas sobre projetos proposto e a garantia de apresentação de opiniões.

In assessing actual or potential adverse human rights impacts, ensure meaningful consultation with potentially affected individuals and communities, paying attention to potentially vulnerable or marginalized groups and ensuring that they have timely and complete information about proposed projects or changes that may affect them and the capacity to put forward their opinions. ${ }^{46}$

Havendo um diálogo prévio entre as partes, em que as preocupações da sociedade civil sejam de fato levadas em conta, os riscos de violações a direitos humanos diminuem bastante, trazendo transparência para os empreendimentos.

Por último, quanto às recomendações para as organizações da sociedade civil, o Grupo de Trabalho reconhece o trabalho que tem sido feito pelas diversas organizações, a dificuldade que se tem diante das ameaças a defensores dos direitos humanos, havendo inclusive aumento nos casos de mortes de pessoas que reivindicam seus direitos. ${ }^{47}$

Continue to raise awareness about the respective obligations and responsibilities of the Government and of business enterprises under international human rights law to prevent and address adverse human rights impacts related to the operations of business enterprises. ${ }^{48}$

\footnotetext{
46 Tradução livre dos autores: Para acessar impactos adversos em direitos humanos atuais ou potenciais, assegurar uma consulta verdadeira com indivíduos e comunidades potencialmente afetados, dando atenção aos grupos potencialmente vulneráveis ou marginalizados e assegurando que eles recebam tempestivamente informações completas sobre os projetos propostos ou mudanças que possam afetá-los e assegurando que possam expor suas opiniões. UNITED NATIONS. Report of the Working Group on the issue of human rights and transnational corporations and other business enterprises on its mission to Brazil. Disponível em https://documents-ddsny.un.org/doc/UNDOC/GEN/G16/096/43/PDF/G1609643.pdf?OpenElement. Acessado em 09.11 .2017 , p. 22.

47 UNITED NATIONS. Declaração ao final da visita ao Brasil do Grupo de Trabalho das Nações Unidas sobre Empresas e Direitos Humanos. Disponível em http://www.ohchr.org/Documents/Issues/Business/WG_Visits/20151215_EOM_statement_Brazil_p ortuguese.pdf. Acessado em 09.11.2017, p 7.

48 Tradução livre dos autores: Continuar aumentando a conscientização sobre as respectivas obrigações e responsabilidades dos governos e empresas sob o direito internacional dos direitos humanos para prevenir e enfrentar impactos adversos nos direitos humanos relacionados com as
} 
ASSIS, Vinicius de; PAMPLONA, Danielle Anne. Princípios orientadores das nações unidas e a complexidade de proteção e respeito aos direitos humanos no combate ao trabalho escravo no Brasil. Revista Eletrônica Direito e Política, Programa de Pós-Graduação Stricto Sensu em Ciência Jurídica da UNIVALI, Itajaí, v.14, n.1, $1^{0}$ quadrimestre de 2019. Disponível em: www.univali.br/direitoepolitica - ISSN 1980-7791

Logo, pela análise das conclusões e das recomendações do Grupo de Trabalho das Nações Unidas sobre empresas e direitos humanos, observa-se a ineficácia do aparato protetivo do Estado brasileiro, seja pela relação entre estado e indivíduos, no sentido de respeitar, proteger e implementar direitos, seja pela relação empresas/coletividade/grupos vulneráveis.

\section{PROPOSIÇões DE ENFRENTAMENTO DO TRABALHO ESCRAVO CONTEMPORÂNEO SOB A PERSPECTIVA DOS PRINCÍPIOS RUGGIE}

Dentro da necessidade de proteção e respeito aos direitos humanos está o enfretamento do trabalho escravo contemporâneo, a partir da perspectiva de preservação dos direitos mínimos do trabalhador, necessários à sua dignidade. Tais mecanismos de proteção passam por uma evolução normativa no âmbito internacional e no Brasil, atuação do sistema universal de proteção desses direitos (ONU) e sistemas regionais: Europeu, Interamericano e Africano, bem como o combate por políticas públicas inovadoras que alcancem a responsabilidade do Estado e das empresas.

No âmbito internacional existe regramento, por instrumentos genéricos que não aceitam a existência do trabalho escravo (Declaração Universal dos Direitos Humanos, de 1948, artigo IV; Pacto Internacional dos Direitos Civis e Políticos da ONU, artigo 8 1.; Pacto Internacional dos Direitos Econômicos, Sociais e Culturais da ONU, artigo 6 1.; Convenção Interamericana de Direitos Humanos e Protocolo de São Salvador), e instrumentos específicos (Convenção Suplementar sobre a Abolição da Escravatura, do Tráfico de Escravos e das Instituições e Práticas Análogas à Escravatura, de 1956, artigo 1; Convenção 105 da Organização Internacional do Trabalho, artigo $1^{\circ}$ ).

atividades empresariais. UNITED NATIONS. Report of the Working Group on the issue of human rights and transnational corporations and other business enterprises on its mission to Brazil. Disponível em hts://documents-ddsny.un.org/doc/UNDOC/GEN/G16/096/43/PDF/G1609643.pdf?OpenElement. Acessado em 09.11.2017, p. 23. 
ASSIS, Vinicius de; PAMPLONA, Danielle Anne. Princípios orientadores das nações unidas e a complexidade de proteção e respeito aos direitos humanos no combate ao trabalho escravo no Brasil. Revista Eletrônica Direito e Política, Programa de Pós-Graduação Stricto Sensu em Ciência Jurídica da UNIVALI, Itajaí, v.14, n.1, 10 quadrimestre de 2019. Disponível em: www.univali.br/direitoepolitica - ISSN 1980-7791

Já no âmbito doméstico a previsão legal encontra-se no plano da Constituição Federal de 1988, em especial nos artigos $5^{\circ}$., III (vedação ao trabalho desumano ou degradante), XIII (liberdade de trabalho) e XLVII (vedação a trabalho forçado, como pena) e 243 (expropriação de propriedades rurais e urbanos, e confisco de bens, em razão de trabalho escravo); e no Código Penal, artigo 149, com redação reformulada pela Lei no 10.803 de 2003, onde especificou o tipo penal com as características de submissão a trabalhos forçados ou a jornada exaustiva, condições degradantes de trabalho e restrição de locomoção por dívida.

Apesar da tentativa de proteção multinível de direitos humanos, há lacunas na previsão de atuação dos Estados na responsabilização de empresas, conforme constatado pelo relatório do Grupo de Trabalho das ONU sobre Empresas e Direitos Humanos no Brasil.

Exemplo dessas violações partem do próprio Estado brasileiro, que, recentemente, editou a portaria no $1.129 / 2017$ do Ministério do Trabalho ${ }^{49}$, onde flexibiliza o conceito de trabalho escravo, dificultando a sua caracterização pela necessidade de preenchimento duplo de critérios para sua caracterização, quais sejam, jornada exaustiva mais privação de ir e vir; condição degradante mais cerceamento de ir

\footnotetext{
49 MiNISTÉRIO DO TRABALHO E EMPREgO. Portaria no 1129/2017

I - trabalho forçado: aquele exercido sem o consentimento por parte do trabalhador e que lhe retire a possibilidade de expressar sua vontade;

II - jornada exaustiva: a submissão do trabalhador, contra a sua vontade e com privação do direito de ir e vir, a trabalho fora dos ditames legais aplicáveis à sua categoria;

III - condição degradante: caracterizada por atos comissivos de violação dos direitos fundamentais da pessoa do trabalhador, consubstanciados no cerceamento da liberdade de ir e vir, seja por meios morais ou físicos, e que impliquem privação da sua dignidade;
}

IV - condição análoga à de escravo:

a) a submissão do trabalhador a trabalho exigido sob ameaça de punição, com uso de coação, realizado de maneira involuntária;

b) o cerceamento do uso de qualquer meio de transporte por parte do trabalhador, com o fim de retêlo no local de trabalho em razão de dívida contraída com o empregador ou preposto, caracterizando isolamento geográfico;

c) a manutenção de segurança armada com o fim de reter o trabalhador no local de trabalho em razão de dívida contraída com o empregador ou preposto;

d) a retenção de documentação pessoal do trabalhador, com o fim de reter o trabalhador no local de trabalho. Disponível em https://www.legisweb.com.br/legislacao/?id=351466. Acessado em 24.11.2017. 
ASSIS, Vinicius de; PAMPLONA, Danielle Anne. Princípios orientadores das nações unidas e a complexidade de proteção e respeito aos direitos humanos no combate ao trabalho escravo no Brasil. Revista Eletrônica Direito e Política, Programa de Pós-Graduação Stricto Sensu em Ciência Jurídica da UNIVALI, Itajaí, v.14, n.1, $1^{0}$ quadrimestre de 2019. Disponível em: www.univali.br/direitoepolitica - ISSN 1980-7791

e vir, dentre outras possibilidades. Essas exigências afrontam o disposto no artigo 149 do Código Penal ${ }^{50}$, que não prevê esse somatório de caracterizações.

É preciso observar que, nestes casos, os Estados são levados aos sistemas de proteção de direitos humanos regionais por conta da atuação de uma empresa e pela falta de sua diligência em evitar a violação. É o que se vê no caso Fazenda Brasil Verde, onde o Estado brasileiro foi demandado no âmbito do Sistema Interamericano de Direitos Humanos, e poderá ser visto, a depender da decisão do judiciário brasileiro, nos casos de indústrias têxteis (casos Zara e M. Officer) que permitem ou não fiscalizam a utilização de mão de obra análoga à escrava em suas cadeias de produção.

Pois bem, como dito no primeiro capítulo, o fenômeno da globalização tem alterado o balanço de poder entre empresas e Estados, enfraquecendo os últimos e fortalecendo os primeiros. Contrapondo-se a isso, a concepção de Estado Democrático de Direito contemporânea exige do Estado a garantia de direitos individuais, resguardando o cidadão do próprio Estado, bem como de terceiros, o que inclui empresas.

A ONU, desde a década de 1970, demonstra preocupação com os impactos das atividades das empresas transnacionais nos direitos humanos e tenta guiar as sociedades neste novo panorama. A criação dos Princípios Ruggie e as visitas a países para a elaboração de relatórios sobre a situação desses quanto aos direitos humanos perante o poder econômico demonstra essa atenção das Nações Unidas para com a temática.

Pertinente, portanto, tendo em vista o novo cenário de forças e as considerações feitas pelo grupo de trabalho da ONU no Brasil, que se estipulem proposições de enfrentamento ao desrespeito a direitos humanos por empresas, em especial a questão do trabalho escravo, sob a perspectiva dos Princípios Ruggie. Pode-se

\footnotetext{
50 Art. 149. Reduzir alguém a condição análoga à de escravo, quer submetendo-o a trabalhos forçados ou a jornada exaustiva, quer sujeitando-o a condições degradantes de trabalho, quer restringindo, por qualquer meio, sua locomoção em razão de dívida contraída com o empregador ou preposto.
} 
ASSIS, Vinicius de; PAMPLONA, Danielle Anne. Princípios orientadores das nações unidas e a complexidade de proteção e respeito aos direitos humanos no combate ao trabalho escravo no Brasil. Revista Eletrônica Direito e Política, Programa de Pós-Graduação Stricto Sensu em Ciência Jurídica da UNIVALI, Itajaí, v.14, n.1, $1^{0}$ quadrimestre de 2019. Disponível em: www.univali.br/direitoepolitica - ISSN 1980-7791

classificar essas propostas em obrigações (duties) do Estado e responsabilidades (responsabilities) das empresas.

Primeiramente, quanto às obrigações do Estado, pode-se propor as seguintes políticas públicas:

a) O Estado brasileiro pode incentivar a formação de cooperativas de trabalhadores, buscando maior investimento na qualificação profissional, proporcionando maior poder de decisão e diminuição das hipóteses de subemprego. Elas facilitam a produção, estimulam a gestão democrática, autonomia e educação. A ONU também destaca a importância dessas organizações para um futuro sustentável. ${ }^{51}$

b) O investimento de recursos financeiros e humanos nos órgãos de fiscalização e controle também é fundamental para o enfrentamento do trabalho escravo contemporâneo. Sem esses órgãos, não há o que se falar em responsabilidade ou mesmo em Estado Democrático de Direito, pois, para a caracterização deste, fazse necessário garantir o respeito das liberdades civis por meio do estabelecimento de uma proteção jurídica, que não ocorre sem uma efetiva fiscalização.

c) A criação de varas especializadas em violação de direitos humanos pode ser outro grande diferencial no embate ao trabalho escravo. Varas especiais proporcionam um ambiente jurídico mais seguro, magistrados mais focados, decisões mais objetivas e possibilita julgamentos mais céleres.

d) A incorporação da noção de imprescritibilidade disposta no Estatuto de Roma é mais uma ação que pode ser tomada como resposta à escravidão. O estatuto em seu art. 70 entende a escravidão como crime contra a humanidade, e que por tal gravidade é um crime não suscetível à prescrição. No entanto, a legislação brasileira não incorporou o disposto nesse estatuto à sua legislação interna.

\footnotetext{
51 ONU. ONU destaca importância das cooperativas para a criação de empregos no mundo. Disponível em https://nacoesunidas.org/onu-destaca-importancia-das-cooperativas-para-a-criacaode-empregos-no-mundo/. Acessado em 27.11.2017
} 
ASSIS, Vinicius de; PAMPLONA, Danielle Anne. Princípios orientadores das nações unidas e a complexidade de proteção e respeito aos direitos humanos no combate ao trabalho escravo no Brasil. Revista Eletrônica Direito e Política, Programa de Pós-Graduação Stricto Sensu em Ciência Jurídica da UNIVALI, Itajaí, v.14, n.1, 10 quadrimestre de 2019. Disponível em: www.univali.br/direitoepolitica - ISSN 1980-7791

e) A expropriação das propriedades rurais e urbanas onde houver exploração de trabalho escravo está no artigo 243 da Constituição Federal. Ocorre que é uma norma constitucional de eficácia limitada, que necessita de legislação infraconstitucional para a sua aplicabilidade. A regulamentação desse dispositivo também é imprescindível para a coibição dessa prática.

f) O Estado de São Paulo inovou com a edição da Lei no 14.946/2013, de combate à escravidão. Essa regulamentação prevê que empresas condenadas em segunda instância, podendo ser tanto na esfera trabalhista quanto na criminal, tenham o registro do ICMS suspenso por dez anos. Sem esse registro, a empresa fica impedida de vender no estado de São Paulo. O texto também determina que os proprietários da empresa condenada fiquem impedidos de exercer o mesmo ramo de atividade econômica ou abrir nova empresa no setor. Essa norma é um exemplo a ser adotado por todos os entes federados.

g) Edição de lei que responsabilize as corporações por qualquer ato de violação de direitos humanos perpetradas em toda sua cadeia produtiva. As grandes empresas hoje possuem uma organização bem complexa, e sem esse tipo de responsabilização, o que ocorre na prática é a impunidade.

h) $O$ art. $4^{0}$ da Lei no $11.948 / 2009$ impede a concessão e renovação de empréstimos pelo BNDES a condenados por assédio moral ou sexual, racismo, trabalho infantil, trabalho escravo ou crime contra o meio ambiente. A proposição feita neste item é de que esta restrição se estenda aos demais bancos públicos.

i) Por último, no que tange às proposições ao Estado, a internalização dos Princípios Ruggie por meio de lei é indispensável para que haja melhor observação dos direitos humanos, tornando-os normas cogentes.

Quanto às empresas, seguem duas proposições:

a) implementação de auditorias que avaliem o impacto real e potencial das atividades sob direitos humanos, visando aprimorar a atuação empresarial, corrigindo eventuais violações de direitos humanos na esfera interna, nas relações 
ASSIS, Vinicius de; PAMPLONA, Danielle Anne. Princípios orientadores das nações unidas e a complexidade de proteção e respeito aos direitos humanos no combate ao trabalho escravo no Brasil. Revista Eletrônica Direito e Política, Programa de Pós-Graduação Stricto Sensu em Ciência Jurídica da UNIVALI, Itajaí, v.14, n.1, 10 quadrimestre de 2019. Disponível em: www.univali.br/direitoepolitica - ISSN 1980-7791

comerciais e na cadeia produtiva, elas estão previstas nos Princípios Ruggie, sob a denominação de due diligence; e

b) melhorar políticas e práticas de responsabilidade social corporativa (RSC), conjugando os conceitos de esfera de influência (poder de decisão na cadeia) e cumplicidade (aufere benefícios), com o intuito de responsabilizar a empresa pela falta de coerência.

O que se observa, portanto, é a necessidade de adoção de medidas que visem à melhora do aparato protetivo dos direitos humanos, subsidiados nos parâmetros dos Princípios Ruggie, com deveres do Estado de respeitar, proteger e implementar direitos, bem como das empresas na sua responsabilização por violações a direitos humanos.

\section{CONSIDERAÇÕES FINAIS}

Inobstante os avanços da globalização, na ordem contemporânea a expansão econômica e as condutas empresariais contribuem para violações aos direitos humanos. A ascensão do poderio das empresas modificou as relações de poder internacional, demandando uma reestruturação de políticas públicas voltadas à proteção e ao respeito aos direitos humanos.

As Nações Unidas, desde a década de 1970, tentam reequilibrar e organizar este novo modelo. Os Princípios Ruggie surgem de um embate de forças entre a visão de progresso econômico e a visão de respeito aos direitos humanos. Suas diretrizes representam um grande avanço para o reconhecimento da responsabilidade das empresas por violações a direitos humanos. Contudo, deve ser encarado como uma etapa para uma futura consolidação da responsabilidade empresarial perante o direito internacional, migrando de instrumentos de soft law para hard law.

Quanto à análise do Relatório do Grupo de Trabalho das Nações Unidas sobre Empresas e Direitos Humanos no Brasil, pode-se concluir desconhecimento dos Princípios Orientadores pelas empresas; insipiente supervisão estatal em grandes projetos de infraestrutura; ausência de consulta prévia e garantia de avaliação dos 
ASSIS, Vinicius de; PAMPLONA, Danielle Anne. Princípios orientadores das nações unidas e a complexidade de proteção e respeito aos direitos humanos no combate ao trabalho escravo no Brasil. Revista Eletrônica Direito e Política, Programa de Pós-Graduação Stricto Sensu em Ciência Jurídica da UNIVALI, Itajaí, v.14, n.1, $1^{0}$ quadrimestre de 2019. Disponível em: www.univali.br/direitoepolitica - ISSN 1980-7791

reais impactos adversos, por meio de consulta em comunidades potencialmente afetadas. Oportunas recomendações do Grupo de Trabalho ao Estado brasileiro e as empresas no sentido de respeito aos direitos humanos, com sua identificação, prevenção, mitigação e transparência na forma em que abordam os impactos adversos.

As proposições de enfrentamento do trabalho escravo contemporâneo sob a perspectiva dos Princípios Ruggie surgem na ambição de implementar novas políticas públicas, dentro da relação Estado, empresas e coletividade, subsidiado nos pilares dos Princípios Orientadores (proteger, respeitar e remediar), no intuito de alcançar a responsabilidade empresarial em direitos humanos.

Portanto, identificada a necessidade de avanços na proteção dos indivíduos, estratégias públicas e privadas devem ser implementadas para conciliar o progresso econômico e os direitos humanos.

\section{REFERÊNCIAS DAS FONTES CITADAS}

BAUMANN-PAULY, Dorothée. Managing Corporate Legitimacy, a toolkit, Greenleaf Publishing Limited, 2013.

BECK, Ulrich. O que é Globalização? Equívocos do Globalismo. Respostas à Globalização. Tradução de André Carone. São Paulo: Paz e Terra, 1999.

BENACCHIO, Marcelo; VAILATTI, Diogo Basilio. Empresas Transnacionais, Globalização e Direitos Humanos. In: BENACCHIO, Marcelo. A Sustentabilidade da Relação entre Empresas Transnacionais e Direitos Humanos. Editora CRV. Curitiba, 2016.

BRASIL. Constituição (1988). Constituição da República Federativa do Brasil. Brasília, DF: Senado Federal: Centro Gráfico, 1988.

CAPRA, Fritjof. Conexões Ocultas. Ciência para uma vida sustentável (Trad. Marcelo Brandão Cipolla). São Paulo: Editora Cultrix, 2002. 
ASSIS, Vinicius de; PAMPLONA, Danielle Anne. Princípios orientadores das nações unidas e a complexidade de proteção e respeito aos direitos humanos no combate ao trabalho escravo no Brasil. Revista Eletrônica Direito e Política, Programa de Pós-Graduação Stricto Sensu em Ciência Jurídica da UNIVALI, Itajaí, v.14, n.1, $1^{0}$ quadrimestre de 2019. Disponível em: www.univali.br/direitoepolitica - ISSN 1980-7791

HACHEM, Daniel Wunder. A maximização dos direitos fundamentais econômicos e sociais pela via administrativa e a promoção do desenvolvimento. Revista Direitos Fundamentais e Democracia, Curitiba, v.13, n.13, p.340-399, jan/jun.2013.

LIMA, Abili Lázaro Castro de. A globalização econômica e a dissipação dos direitos sociais. A\&C Revista de Direito Administrativo e Constitucional, Belo Horizonte, ano 6, n. 26, p. 37-58, out./dez. 2006.

MINISTÉRIO DO TRABALHO E EMPREGO. Portaria no 1129/2017. Disponível em https://www.legisweb.com.br/legislacao/?id=351466. Acessado em 24.11.2017.

ONU. ONU destaca importância das cooperativas para a criação de empregos no mundo. Disponível em https://nacoesunidas.org/onu-destacaimportancia-das-cooperativas-para-a-criacao-de-empregos-no-mundo/. Acessado em 27.11.2017.

PAMPLONA, Danielle Anne. O processo de decisão de questões políticas pelo Supremo Tribunal Federal - a postura do juiz. Tese apresentada ao Curso de Pósgraduação em Direito da Universidade Federal de Santa Catarina como requisito à obtenção do título de Doutor em Direito em 2006. Disponível em http://www.dominiopublico.gov.br/download/teste/arqs/cp022108.pdf. Acessada em 05.11.2017.

RIBEIRO, Daniela Menengoti; OLIVEIRA, José Sebastião. Promoção e Tutela dos Direitos da Personalidade pelas Empresas Transnacionais. In: BENACCHIO, Marcelo. A Sustentabilidade da Relação entre Empresas Transnacionais e Direitos Humanos. Editora CRV. Curitiba, 2016.

RUGGIE, John. UN Guiding Principles on Business and Human Rights. Disponível em https://www.shiftproject.org/un-guiding-principles/. Acessado em 05.11 .2017$.

SHIFT. Pillar I: State Duty to Protect. Disponível em https://www.shiftproject.org/resources/protect/ . Acessado em 07.11.2017. 
ASSIS, Vinicius de; PAMPLONA, Danielle Anne. Princípios orientadores das nações unidas e a complexidade de proteção e respeito aos direitos humanos no combate ao trabalho escravo no Brasil. Revista Eletrônica Direito e Política, Programa de Pós-Graduação Stricto Sensu em Ciência Jurídica da UNIVALI, Itajaí, v.14, n.1, $1^{0}$ quadrimestre de 2019. Disponível em: www.univali.br/direitoepolitica - ISSN 1980-7791

SILVA, Ana Rachel Freitas da; PAMPLONA, Danielle Anne. Os Princípios Orientadores das Nações Unidas sobre Empresas e Direitos Humanos: houve avanços? In: BENACCHIO, Marcelo (coord.). A Sustentabilidade da Relação entre Empresas Transnacionais e Direitos Humanos. Editora CRV. Curitiba, 2016.

SILVEIRA, Edson Damas da. RAMOS JÚNIOR, Dempsey Pereira. Globalização multicultural, direitos universais humanos e socioambientais. Revista Direito Econômico e Socioambiental, Curitiba, v.2, n.1, p. 11-39, jan/jun. 2011.

UNITED NATIONS. Declaração ao final da visita ao Brasil do Grupo de Trabalho das Nações Unidas sobre Empresas e Direitos Humanos. Disponível em http://www.ohchr.org/Documents/Issues/Business/WG_Visits/20151215_EOM_st atement_Brazil_portuguese.pdf. Acessado em 09.11.2017.

UNITED NATIONS. Report of the Working Group on the issue of human rights and transnational corporations and other business enterprises on its mission to Brazil. Disponível em https://documents-ddsny.un.org/doc/UNDOC/GEN/G16/096/43/PDF/G1609643.pdf?OpenElement. Acessado em 09.11.2017.

RECEBIDO EM: 14/03/2019

APROVADO EM: 14/04/2019 